\title{
Impact of land management system on crop yields and soil fertility in Cameroon
}

\author{
D. Tsozué ${ }^{1}$, J. P. Nghonda ${ }^{2}$, and D. L. Mekem ${ }^{3}$ \\ ${ }^{1}$ Department of Earth Sciences, Faculty of Sciences, University of Maroua, P.O. Box 814, Maroua, Cameroon \\ ${ }^{2}$ National Institute of Cartography, P.O. Box 157, Yaoundé, Cameroon \\ ${ }^{3}$ Department of Environmental Sciences, Higher Institute of the Sahel, University of Maroua, P.O. Box 46, Maroua, Cameroon
}

Correspondence to: D. Tsozué (tsozudsir@yahoo.fr)

Received: 5 May 2015 - Published in Solid Earth Discuss.: 16 June 2015

Revised: 3 August 2015 - Accepted: 11 September 2015 - Published: 30 September 2015

\begin{abstract}
The impact of direct-seeding mulch-based cropping systems (DMC), direct seeding (DS) and tillage seeding (TS) on Sorghum yields, soil fertility and the rehabilitation of degraded soils was evaluated in northern Cameroon. Field work consisted of visual examination, soil sampling, yield and rainfall data collection. Three fertilization rates $\left(\mathrm{F} 1: 100 \mathrm{~kg} \mathrm{ha}^{-1} \mathrm{NPK}+25 \mathrm{~kg} \mathrm{ha}^{-1}\right.$ of urea in DMC, F2: $200 \mathrm{~kg} \mathrm{ha}^{-1} \mathrm{NPK}+50 \mathrm{~kg} \mathrm{ha}^{-1}$ of urea in DMC and F3: $300 \mathrm{~kg} \mathrm{ha}^{-1} \mathrm{NPK}+100 \mathrm{~kg} \mathrm{ha}^{-1}$ of urea in DMC) were applied to each cropping system (DS, TS and DMC), resulting in nine experimental plots. Two types of chemical fertilizer were used (NPK 22.10.15 and urea) and applied each year from 2002 to 2012. Average Sorghum yields were 1239, 863 and $960 \mathrm{~kg} \mathrm{ha}^{-1}$ in DMC, DS and TS, respectively, at F1, 1658, 1139 and $1192 \mathrm{~kg} \mathrm{ha}^{-1}$ in DMC, DS and TS, respectively, at F2, and 2270, 2138 and $1780 \mathrm{~kg} \mathrm{ha}^{-1}$ in DMC, DS and TS, respectively, at F3. pH values were 5.2-5.7 under DMC, 4.9-5.3 under DS and TS and 5.6 in the control sample. High values of cation exchange capacity were recorded in the control sample, TS system and F1 of DMC. Base saturation rates, total nitrogen and organic matter contents were higher in the control sample and DMC than in the other systems. All studied soils were permanently not suitable for Sorghum due to the high percentage of nodules. F1 and F2 of the DS were currently not suitable, while F1 and F3 of DMC, F3 of DS and F1, F2 and F3 of TS were marginally suitable for Sorghum due to low $\mathrm{pH}$ values.
\end{abstract}

\section{Introduction}

Drought, desertification and other types of land degradation currently affect more than 2 billion people in the world (Gabathuler et al., 2009). The situation might worsen due to unsustainable use of soil and water under present scenarios of climate change (Gabathuler et al., 2009; Muluneh et al., 2014). Soil loss is a worldwide risk and adversely affects the productivity of all natural ecosystems as well as agricultural, forest and rangeland ecosystems (Pimentel et al., 1995; Pimentel, 2006; Perkins et al., 2013; Lemenih et al., 2014; Van Leeuwen et al., 2015). Changes in soil quality affected by accelerated erosion are significant and have resulted in decreased production and land abandonment (Pimentel et al., 1995). Worldwide, annual cropped-soil erosion rates are about $30 \mathrm{Mg} \mathrm{ha}^{-1}$, on average, ranging from 0.5 to $400 \mathrm{Mg} \mathrm{ha}^{-1} \mathrm{yr}^{-1}$ (Pimentel et al., 1995; Cerdà et al., 2009a, b; Biro et al., 2013; Leh et al., 2013; Mandal et al., 2013; Zhao et al., 2013; Lieskovský and Kenderessy, 2014). As a result, during the last 40 years, about $30 \%$ of the world's arable land has become unproductive and a great part of it has been abandoned (Kendall and Pimentel, 1994; WRI, 1994; Cerdà, 2000). Sustainable soil management in agricultural land is needed for a sustainable world (Costa et al., 2015). According to Myers (1993), soil erosion is 90 times greater in agricultural land than in natural forest areas. Rainfallinduced erosion is the most important factor of cultivated soil degradation in tropical zones, and particularly in subhumid areas such as Sudanese savannas (Bilgo et al., 2006). Tropical soils are especially threatened by population growth and increased pressure on soil resources (Lemenih, 2004). 
Cropping systems are generally characterized by high nutrient losses, especially for N, P and K (Smaling, 1993; Tabi et al., 2013). Long-term processes that adversely affect sustainability, such as decrease and eventual depletion of soil nutrient stocks, are not readily apparent and receive little attention (Ehabe et al., 2010). In the northern Cameroon savannas, inappropriate agricultural practices (e.g. monoculture crop production, non-adoption of soil-conservation management practices, overcutting of vegetation, unbalanced fertilization, the excessive use of groundwater for irrigation, improper use of pesticides, the use of heavy machinery and overgrazing) on fragile soils contribute to soil organic matter losses and to increased water and wind erosion risks, leading to soil physical degradation and to the decline of the soil production potential (Boli, 1996). Loss of soil organic matter leads to decreased cation exchange capacity and weakening of soil structure (Roose, 1994). Exportation of crop residues reduces the stock of easily exchangeable elements, leading, after 4 years, to the mineralization of soil organic matter by $50 \%$ and to the leaching of some of the released nutrients (Kang and Juo, 1982), therefore exposing the soils to erosion (Harmand et al., 2000). Degradation of these fragile soils is expressed both in the rainy and the dry season and loss of land ranges from 0.5 to $40 \mathrm{Mg} \mathrm{ha}^{-1} \mathrm{yr}^{-1}$ under crops on the long ferruginous tropical glacis of Sudano-Sahelian regions (Boli et al., 1991). This leads to the development of infertile soils called hardé soils, the most striking sign of land degradation, characterized by vast expansion of bare soils (Boli, 1996; Tsozué et al., 2014). One of the spontaneous responses to the decline of soil fertility is the extension of cultivated surface on lands that are sometimes marginal, instead of increased or improved existing production systems (Dongmo, 2009). The expansion of agriculture, which operates continuously and without restitution of organic matter, contributes to soil erosion on a large scale. It increases in a socio-economic context characterized by poverty, growing population and increasingly unfavourable climatic conditions which prevail in northern Cameroon. However, farmland in the Sudano-Sahelian zone of Cameroon has a high potential, but only if farming systems rely on water conservation and maintenance of soil fertility through better valorization of plant biomass, forage or cultivated trees (Landais and Lhoste, 1990).

Practices such as direct-seeding mulch-based cropping (DMC) have permitted a better control of erosion, an important reduction in the cost of production and restoration of soil fertility (Marasas et al., 2001; Brown et al., 2002; Ndah et al., 2015). They have been introduced in north Cameroon since the first decade of the 21st century. Experimentation of DMC systems in juxtaposition to conventional cropping systems, tillage seeding (TS) and direct seeding (DS), therefore raises many uncertainties about the expected results. The main objective of this paper is to evaluate the impact of different types of management (DS, TS and DMC) at different levels of fertilization in Sorghum-cropped soils (Sorghum is

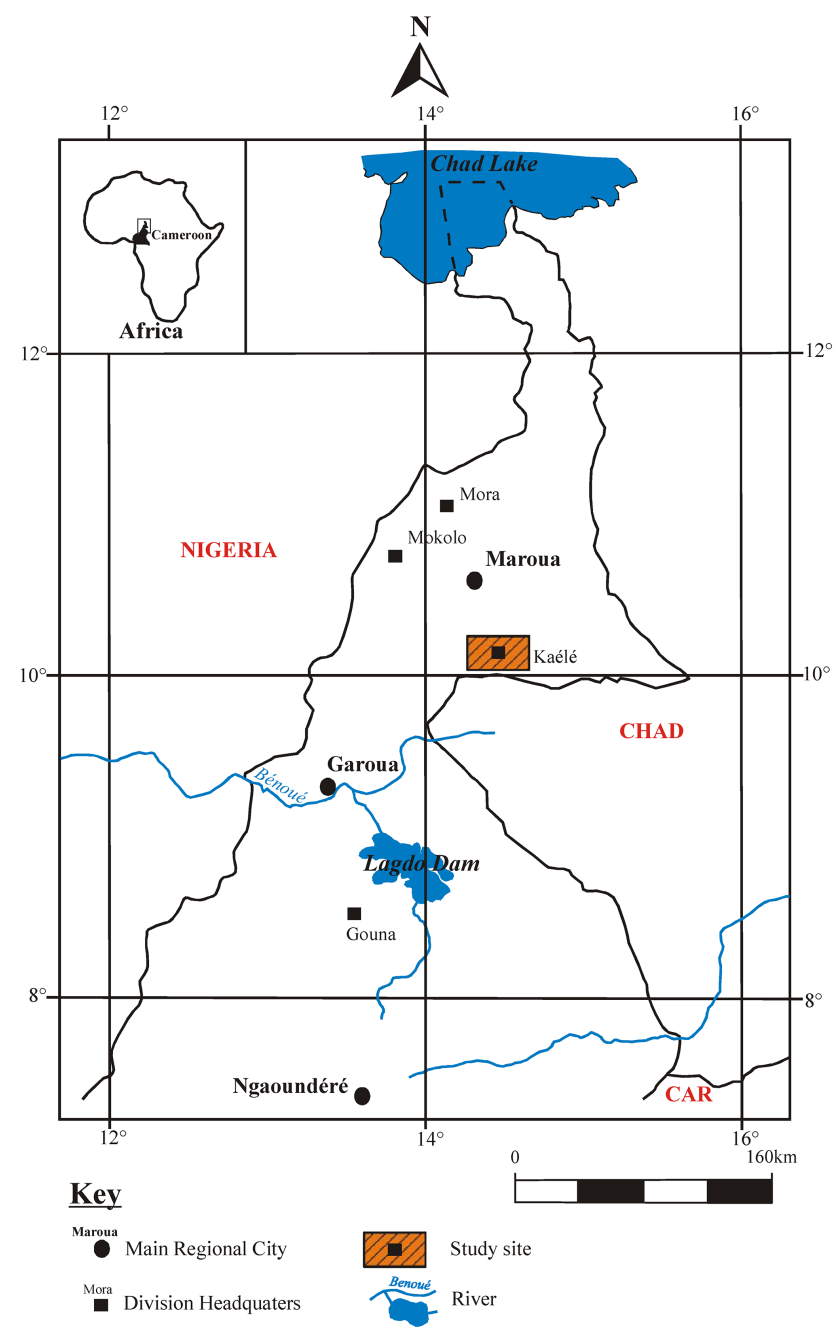

Figure 1. Location of the study site.

a representative crop in the study area), on soil fertility and the rehabilitation of hardé soils in the Far North region of Cameroon.

\section{Material and methods}

\subsection{Study site}

The study was conducted in the experimental site of SODECOTON (Société de Développement du coton au Cameroun) at Kaélé, specifically in Zouana quarter $\left(10^{\circ} 04^{\prime} 48^{\prime \prime} \mathrm{N}\right.$, $14^{\circ} 33^{\prime} 36^{\prime \prime} \mathrm{E}, 380 \mathrm{~m}$ a.s.l.), Mayo-Kani division, northern Cameroon (Fig. 1). This region belongs to Kaélé-Mindif pseudo-pediplain, with elevation ranging between 400 and $430 \mathrm{~m}$ a.s.l. The general climate is semi-arid, characterized by a mean annual rainfall of about $800 \mathrm{~mm}$ and a mean annual temperature of about $28^{\circ} \mathrm{C}$, with 8 months of dry season (Suchel, 1987). The relief is smooth, with slopes typically below $5 \%$. The vegetation is composed mainly of Acacia seyal, 
Table 1. Different levels of fertilization (source: SODECOTON site).

\begin{tabular}{|c|c|c|c|}
\hline Level of fertilization & DS & TS & DMC \\
\hline $\mathrm{F} 1$ & $100 \mathrm{~kg} \mathrm{ha}^{-1}$ NPK 22.10 .15 & $100 \mathrm{~kg} \mathrm{ha}^{-1}$ NPK 22.10 .15 & $\begin{array}{l}100 \mathrm{~kg} \mathrm{ha}^{-1} \text { NPK } 22.10 .15 \\
+25 \mathrm{~kg} \mathrm{ha}^{-1} \text { of urea }\end{array}$ \\
\hline $\mathrm{F} 2$ & $200 \mathrm{~kg} \mathrm{ha}^{-1}$ NPK 22.10 .15 & $200 \mathrm{~kg} \mathrm{ha}^{-1}$ NPK 22.10 .15 & $\begin{array}{l}200 \mathrm{~kg} \mathrm{ha}^{-1} \text { NPK } 22.10 .15 \\
+50 \mathrm{~kg} \mathrm{ha}^{-1} \text { of urea }\end{array}$ \\
\hline F3 & $\begin{array}{l}300 \mathrm{~kg} \mathrm{ha}^{-1} \text { NPK } 22.10 .15 \\
+50 \mathrm{~kg} \mathrm{ha}^{-1} \text { of urea }\end{array}$ & $\begin{array}{l}300 \mathrm{~kg} \mathrm{ha}^{-1} \mathrm{NPK} 22.10 .15 \\
+50 \mathrm{~kg} \mathrm{ha}^{-1} \text { of urea }\end{array}$ & $\begin{array}{l}300 \mathrm{~kg} \mathrm{ha}^{-1} \mathrm{NPK} 22.10 .15 \\
+100 \mathrm{~kg} \mathrm{ha}^{-1} \text { of urea }\end{array}$ \\
\hline
\end{tabular}

F1-F3 are levels of fertilization; DS: direct seeding; TS: tillage seeding; DMC: direct-seeding mulch-based cropping systems.

Acacia hockii, Balanites aegyptiaca, Anogeissus leiocarpus, Sterculia setigera and Scleorcarya birrea (Letouzey, 1985). The bedrock is a calc-alkaline granite constituted of potassium feldspar, plagioclase, quartz, amphibole, biotite and opaque minerals. Soils developed here are luvisols (WRB, 2006).

Sorghum was intercropped with Brachiaria ruziziensis, also called Congo grass. It is a forage crop that is grown throughout the humid tropics (Husson et al., 2008; Naudin, 2012). It requires well-drained soils with low clay contents, moderate to high fertility and does not tolerate strong acidic conditions. It also requires a reasonably high rainfall (1000 $\mathrm{mm} \mathrm{yr}^{-1}$ or more), although it can resist drought periods.

\subsection{Experimental design and soil sampling}

Field work consisted of direct observations, soil sampling, crop yield and rainfall data collection. According to Fig. 2, three soil samples were collected per experiment. Three fertilization rates (F1, F2 and F3) were applied to each cropping system (DS, TS and DMC), resulting in nine experimental plots (three fertilization rates for three types of management) (Table 1). On TS plots, tillage was done after a significant rain event with an ox-drawn plough to $10-15 \mathrm{~cm}$ depth at the end of each June. On DS plots, Sorghum was sown by hand with a hoe with no disturbance of the soil surface outside the mounds. Sowing was done in all plots at the beginning of each June. For TS and DS, ridging and weed control were performed by hand with a hoe at the end of July. In DMC and DS, herbicide for seed lift-off was sprayed before sowing (Diuron at $550 \mathrm{~g} \mathrm{ha}^{-1}$ and glyphosate at $720 \mathrm{~g} \mathrm{ha}^{-1}$ ). In DMC plots, from the second year, Sorghum was sown on the residual mulch. Remaining residues from the previous crop were retained on the soil surface, protected from grazing by a live fence and from fire by a firebreak. In DCM plots, weed control was done by hand or herbicide. Cropping systems and plots were separated respectively by a corridor, $3 \mathrm{~m}$ wide, and earth mounds (Fig. 2). Two types of chemical fertilizer were used (NPK 22.10.15 and urea 46N 0P 0K) and applied each year from 2002 to 2012 in the middle of July and supplement urea in DCM after 1 week. Sorghum and Brachiaria are de- scribed as nitrogen-demanding plants. This justifies the fact that fertilizer doses applied in the cropping systems have a high percentage of nitrogen (22\%) compared to potassium $(15 \%)$ and phosphorus $(10 \%)$, and there is an additional supply of nitrogen in the form of urea in the DCM system. In each plot, soil samples were collected in triplicate (Fig. 2) between 0 and $15 \mathrm{~cm}$ depth (Ap horizon) in January 2013 and mixed to obtain a composite sample. Ten composite soil samples were then collected in the dry season after crop harvest for laboratory analyses, one soil sample from the Ap horizon of each of the nine plots and a control soil sample in a plot which has not been cultivated since the beginning of the experiment in 2002.

After collection, soil samples were packaged in plastic bags, labelled and sent to the laboratory for analyses. In the laboratory, bulk soil samples were air-dried at room temperature and then sieved $(2 \mathrm{~mm})$ to discard coarse fragments. Analyses were carried out on the fine fraction, and include particle size distribution, $\mathrm{pH}$, exchangeable bases, cation exchange capacity (CEC) at $\mathrm{pH} 7$, organic carbon, total nitrogen and available phosphorus.

For soil texture analysis, soil organic matter and carbonates were removed with hydrogen peroxide $(30 \%)$ and diluted hydrochloric acid (10\%), respectively. Then, soil samples were dispersed with sodium hexametaphosphate and particle size distribution was analysed by the pipette method. Soil $\mathrm{pH}$ was measured potentiometrically in a $1: 2.5$ soil: solution ratio. Exchangeable bases and CEC were determined using atomic absorption spectrophotometry in a solution of ammonium acetate at $\mathrm{pH}$ 7. Total nitrogen was obtained after heat treatment of each sample in a mixture of concentrated sulfuric acid and salicylic acid. The mineralization was accelerated by a catalyst consisting of iron sulfate, selenium and potassium sulfate. The mineralization was followed by distillation via conversion of nitrogen into steam in the form of ammonia $\left(\mathrm{NH}_{3}\right)$, after alkalinization of mineralized extract with $\mathrm{NaOH}$. The distillate was fixed in boric acid $\left(\mathrm{H}_{3} \mathrm{BO}_{3}\right)$ and then titrated with sulfuric acid or diluted hydrochloric acid $(0.01 \mathrm{~N})$. Organic carbon was determined by the Walkley-Black method (Walkley and Black, 1934). Soil organic matter (OM) content was obtained by multiplying soil organic carbon content by 1.724 (Walkley 


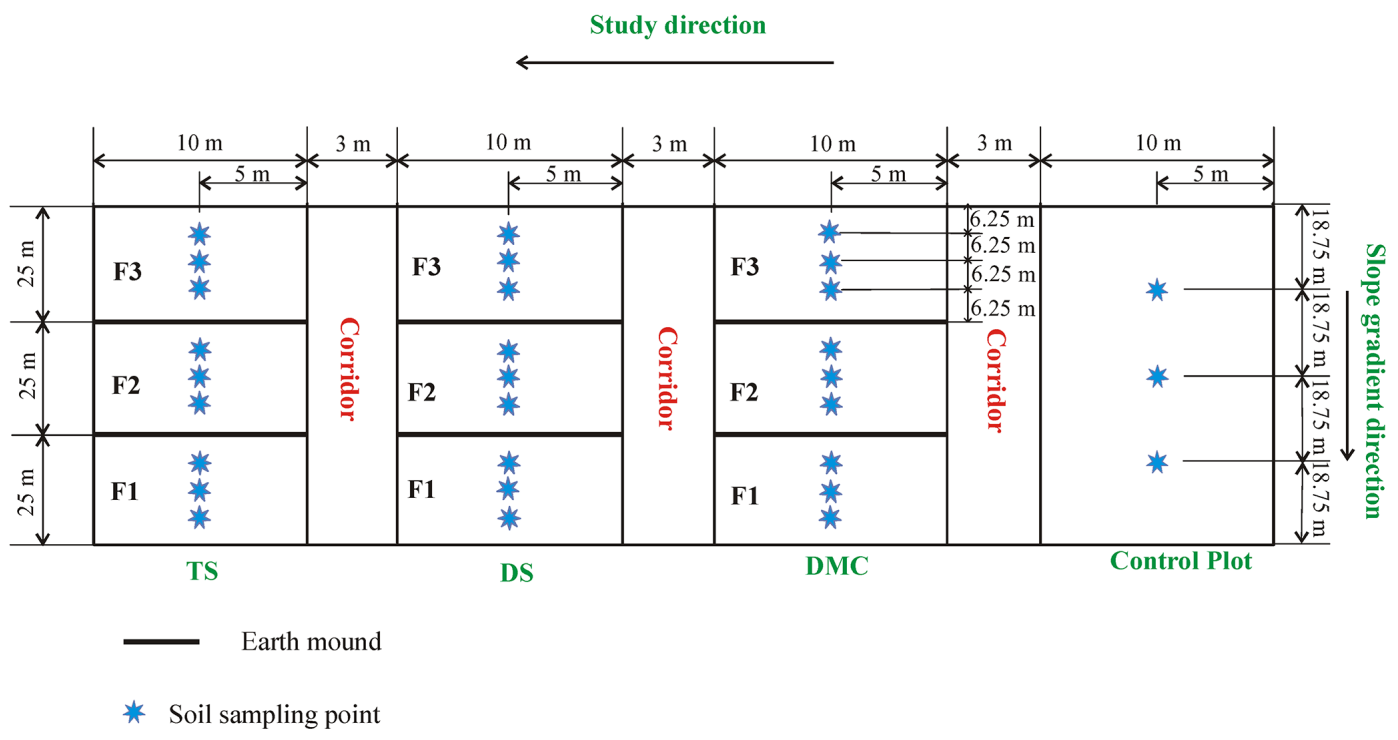

Figure 2. Study and soil sampling plan.

and Black, 1934). Available phosphorus was determined by Bray-2 method (Bray and Kurtz, 1945).

In order to identify the soil or the climatic parameters which have previously limited the growth and production of Sorghum and to investigate possible changes after treatments, soils were evaluated for Sorghum following the method of Sys et al. (1991a, b, 1993). Soils' suitability for Sorghum was classified as being highly suitable (S1), moderately suitable (S2), marginally suitable (S3), actually not, but potentially suitable (N1) and actually and potentially not suitable (N2), using simple limitation and parametric methods.

The differences among different treatments (DCM, DS and TS) were tested $(p<0.05)$ using one-way analysis of variance (ANOVA). This test was performed using Statgraphics Plus for Windows 5.0 (Manugistics Inc. Rockville, $\mathrm{MD})$. Correlations between yields and rainfall were calculated to check whether rainfall has an impact on yield levels obtained in each cropping system and each fertilization level. Sorghum yields under each type of management and annual rainfall data between 2002 and 2012 were obtained from the SODECOTON reports (2002-2012).

\section{Results}

\subsection{Macroscopic organization of the soil profile of the experimental site}

Generally, soils from the studied site showed an Ap-B-C profile. The following were characteristics of soils in the control plot:

- 0-15 cm: an Ap horizon, compact, characterized by a grey-brown colour (10YR5/2), a sandy loam texture, a very weak matrix and tubular porosity; loose dry and fri- able moist; non-sticky and non-plastic wet; the presence of very rare millimetre nodules and rootlets; distinct and irregular boundary;

- >15 cm: a nodular B horizon, constituted of more than $90 \%$ of nodules, embedded in a fine matrix with reddish-brown colour (5YR5/4) and clayey texture; hard dry, friable moist, sticky and plastic wet matrix; millimetre to centimetre nodules, irregularly shaped, indurated with globally smooth and reddish fracture, sometimes with dark patches; fine weakly developed tubular pores and rare rootlets.

\subsection{Sorghum yields}

At the fertilization level F1, from 2002 to 2003, Sorghum yields in DMC systems and in DS were lower than those obtained in the TS (Table 2). From 2004 to 2012, yields in DMC systems were greater than yields in DS and TS, except in 2011 where yields in DS were the highest. However, in DMC systems, Sorghum yields in the years 2007, 2009 and 2011 were lower than in 2002. The highest yield was obtained in 2004 and the lowest one in 2009. In DS, the highest yield was obtained in 2005, while the lowest yield was obtained in 2008. In 2003, yields were better in the TS than in the other cropping systems $\left(1523 \mathrm{~kg} \mathrm{ha}^{-1}\right)$. In 2011 , they were very low, reaching a value of $380 \mathrm{~kg} \mathrm{ha}^{-1}$, a value not obtained in any cropping system. Globally, the average yields of Sorghum in different cropping systems from 2002 to 2012 were $1239 \mathrm{~kg} \mathrm{ha}^{-1}$ for DMC systems, $863 \mathrm{~kg} \mathrm{ha}^{-1}$ for DS and $960 \mathrm{~kg} \mathrm{ha}^{-1}$ for TS. There was a significant difference $(p<0.05)$ between yields in DMC, DS and TS. Yields were moderately variable in DMC (coefficient of variation 
Table 2. Yields in $\mathrm{kg} \mathrm{ha}^{-1}$ at different level of fertilization (F1, F2, F3) and mean annual rainfall over the studied site from 2002 to 2012 (Source: SODECOTON).

\begin{tabular}{|c|c|c|c|c|c|c|c|c|c|c|}
\hline \multirow[t]{2}{*}{ Years } & \multirow{2}{*}{$\begin{array}{l}\text { Rainfall } \\
\text { (mm) }\end{array}$} & \multicolumn{3}{|c|}{ Level of fertilization F1 } & \multicolumn{3}{|c|}{ Level of fertilization F2 } & \multicolumn{3}{|c|}{ Level of fertilization F3 } \\
\hline & & $\mathrm{DMC}$ & DS & $\mathrm{TS}$ & DMC & DS & TS & DMC & DS & TS \\
\hline 2002 & 546 & 918 & 689 & 1062 & 776 & 605 & 1078 & 1208 & 1819 & 1823 \\
\hline 2003 & 863 & 1146 & 1104 & 1523 & 1423 & 1521 & 1797 & 1729 & 1875 & 2083 \\
\hline 2004 & 710 & 2067 & 1134 & 1507 & 2625 & 1528 & 1587 & 2852 & 3733 & 2444 \\
\hline 2005 & 711 & 1473 & 1335 & 1468 & 1932 & 2202 & 1889 & 2435 & 2739 & 2736 \\
\hline 2006 & 1003 & 1530 & 764 & 526 & 2034 & 1090 & 778 & 2901 & 2545 & 1735 \\
\hline 2007 & 868 & 844 & 564 & 800 & 1430 & 1252 & 753 & 2035 & 2097 & 755 \\
\hline 2008 & 998 & 1420 & 540 & 820 & 1380 & 800 & 1220 & 2670 & 1270 & 1730 \\
\hline 2009 & 738 & 700 & 700 & 600 & 1390 & 1535 & 1050 & 2500 & 2500 & 1750 \\
\hline 2010 & 1147 & 1470 & 860 & 1030 & 1730 & 920 & 1370 & 2390 & 1370 & 2010 \\
\hline 2011 & 805 & 750 & 880 & 380 & 1730 & 130 & 430 & 2280 & 1680 & 820 \\
\hline 2012 & 835 & 1320 & 930 & 850 & 1780 & 940 & 1150 & 1980 & 1900 & 1690 \\
\hline Mean & 838 & 1239 & 863 & 960 & 1658 & 1139 & 1192 & 2270 & 2138 & 1779 \\
\hline \multicolumn{2}{|c|}{$\mathrm{CV}$} & 0.32 & 0.28 & 0.40 & 0.27 & 0.47 & 0.36 & 0.21 & 0.32 & 0.32 \\
\hline \multicolumn{2}{|c|}{ SD } & 396 & 242 & 384 & 448 & 535 & 429 & 477 & 684 & 569 \\
\hline
\end{tabular}

$\mathrm{CV}$ : coefficient of variation; SD: standard deviation.

$(\mathrm{CV})=32 \%)$ and $\mathrm{DS}$ systems $(\mathrm{CV}=28 \%)$, and highly variable in the TS system $(\mathrm{CV}=40 \%)$ (Table 2$)$.

Sorghum yields at fertilization level F2 were expressed in the same way as in fertilization level F1. In the years 2002 and 2003, Sorghum yields in DMC systems and DS were lower than those obtained in the TS (Table 2). Higher yields in DMC systems were reached in 2004. In the same interval of time, Sorghum yields in DS increased from 2002 to 2005, and then declined until 2012. 2011 had experienced the worst agricultural yields in DS and TS, with 130 and $430 \mathrm{~kg} \mathrm{ha}^{-1}$, respectively. Highest yields were recorded in 2005. In the TS, yields were often above $1000 \mathrm{~kg} \mathrm{ha}^{-1}$, except for the years 2006, 2007 and 2011. It was also in 2005 that the yields were better. In general, the average yields of Sorghum in DMC, DS and TS from 2002 to 2012 were 1658, 1139 and $1192 \mathrm{~kg} \mathrm{ha}^{-1}$, respectively. With reference to $\mathrm{F} 1$, there was an increase in yields of $419 \mathrm{~kg} \mathrm{ha}^{-1}$ for DCM, $276 \mathrm{~kg} \mathrm{ha}^{-1}$ for DS and $232 \mathrm{~kg} \mathrm{ha}^{-1}$ for TS. There was a significant difference $(p<0.05)$ between yields in DMC, DS and TS. Yields were moderately variable in $\mathrm{DMC}(\mathrm{CV}=27 \%)$, but highly variable in $\mathrm{DS}(\mathrm{CV}=47 \%)$ and $\mathrm{TS}$ systems $(\mathrm{CV}=36 \%)$ (Table 2).

From 2002 to 2012, the difference of Sorghum yields at F3 fertilization level between DMC, DS and TS were not very meaningful (Table 2). The difference in yields between the three treatments was remarkable from 2004, where yields under TS became lower than those under the other systems. In DMC and DS systems, Sorghum yields were about $2000 \mathrm{~kg} \mathrm{ha}^{-1}$. In DS, maximum yield was achieved in 2004, contrary to other systems. Therefore, Sorghum yields tended to be equal in DMC and DS systems at fertilization F3. Between 2002 and 2012, the average yield of Sorghum was $2270 \mathrm{~kg} \mathrm{ha}^{-1}$ in DMC, $2138 \mathrm{~kg} \mathrm{ha}^{-1}$ in DS, but only $1780 \mathrm{~kg} \mathrm{ha}^{-1}$ in TS. With reference to F2, there was an increase in yields of $612 \mathrm{~kg} \mathrm{ha}^{-1}$ for DMC, $999 \mathrm{~kg} \mathrm{ha}^{-1}$ for DS and $588 \mathrm{~kg} \mathrm{ha}^{-1}$ for TS. With reference to $\mathrm{F} 1$, there was an increase in yields of $1031 \mathrm{~kg} \mathrm{ha}^{-1}$ for DMC, $1275 \mathrm{~kg} \mathrm{ha}^{-1}$ for DS and $820 \mathrm{~kg} \mathrm{ha}^{-1}$ for TS. Globally, there were differences in average yields; however no significant differences were shown between the three treatments $(P>0.05)$. Yields were moderately variable in all three systems. $\mathrm{CV}$ values were $21 \%$ in the DMC system and $32 \%$ in DS and TS systems (Table 2).

\subsection{Physical and chemical characteristics of soils}

Concerning the impact of land management on the soil texture, sand contents of soils in all plots were high and ranged from a low value of $41 \%$ in DS and F1 fertilization level, to a high value of $66 \%$ in the same cropping system but in F3 fertilization level. Clay and silt contents were globally low, varying between 11 and $31 \%$ for clay and 19 and $35 \%$ for silt (Table 3 ). Textural classes were sandy clay loam to loam (DMC), clay loam to sandy loam (DS) and sandy loam (TS and control sample). Sand contents were slightly variable $(\mathrm{CV}<15 \%)$ while that of silt and clay were moderately variable $(15 \%<\mathrm{CV}<35 \%)$ in all the three systems (Table 3$)$. Generally, $\mathrm{pH}(1: 2.5$ soil : water) values varied from 4.9 to 5.7. These values were slightly variable in all the three systems (Table 3). Calcium and magnesium dominated the exchange complex. High values of sum of bases were obtained in the control sample $\left(8.1 \mathrm{cmol}(+) \mathrm{kg}^{-1}\right)$ and in the DMC system $\left(6.95-11.01 \mathrm{cmol}(+) \mathrm{kg}^{-1}\right)$. CEC values were weak and high values were recorded in the control sample $\left(20.16 \mathrm{cmol}(+) \mathrm{kg}^{-1}\right)$, in all fertilization levels 
Table 3. Particle size distribution and acidity of the studied soils.

\begin{tabular}{|c|c|c|c|c|c|c|c|c|}
\hline & \multirow{2}{*}{$\begin{array}{l}\text { Fertilization } \\
\text { level }\end{array}$} & \multicolumn{4}{|c|}{ Particle size distribution (\%) } & \multicolumn{3}{|c|}{ Acidity } \\
\hline & & Sand & Silt & Clay & Textural classes & $\mathrm{pH}_{\mathrm{H}_{2} \mathrm{O}}$ & $\mathrm{pH}_{\mathrm{KCl}}$ & $\Delta \mathrm{pH}$ \\
\hline \multirow[t]{3}{*}{$\mathrm{DMC}$} & $\mathrm{F} 1$ & 62 & 18 & 20 & Sandy clay loam & 5.2 & 4.4 & -0.8 \\
\hline & $\mathrm{F} 2$ & 51 & 22 & 27 & Sandy clay loam & 5.7 & 4.6 & -1.1 \\
\hline & F3 & 45 & 33 & 22 & Loam & 5.3 & 4.0 & -1.3 \\
\hline \multirow[t]{3}{*}{ DS } & $\mathrm{F} 1$ & 41 & 28 & 31 & Clay loam & 5.1 & 3.8 & -1.3 \\
\hline & $\mathrm{F} 2$ & 60 & 20 & 20 & Sandy clay loam & 4.9 & 3.6 & -1.3 \\
\hline & F3 & 66 & 19 & 15 & Sandy loam & 5.3 & 4.2 & -1.1 \\
\hline \multirow[t]{3}{*}{ TS } & $\mathrm{F} 1$ & 54 & 35 & 11 & Sandy loam & 5.2 & 3.9 & -1.3 \\
\hline & $\mathrm{F} 2$ & 61 & 23 & 16 & Sandy loam & 5.3 & 3.8 & -1.5 \\
\hline & F3 & 62 & 25 & 13 & Sandy loam & 5.2 & 4.1 & -1.1 \\
\hline Control sample & - & 64 & 21 & 15 & Sandy loam & 5.6 & 4.4 & -1.2 \\
\hline \multicolumn{2}{|c|}{$\mathrm{CV}$} & 0.145 & 0.231 & 0.317 & - & 0.038 & 0.074 & -0.157 \\
\hline \multicolumn{2}{|c|}{ SD } & 8.09 & 5.72 & 6.16 & - & 0.20 & 0.30 & 0.19 \\
\hline
\end{tabular}

$\mathrm{CV}$ : coefficient of variation; SD: standard deviation.

Table 4. Chemical properties of the studied soils.

\begin{tabular}{|c|c|c|c|c|c|c|c|c|c|c|c|c|c|c|c|}
\hline & \multirow[t]{2}{*}{$\begin{array}{l}\text { Fertilization } \\
\text { level }\end{array}$} & \multicolumn{5}{|c|}{$\begin{array}{l}\text { Exchangeable bases } \\
\text { cmol }(+) \mathrm{kg}^{-1}\end{array}$} & \multirow[t]{2}{*}{$\begin{array}{r}\text { CEC } 7 \text { soil } \\
\mathrm{cmol}^{(+)} \mathrm{kg}^{-1}\end{array}$} & \multirow[t]{2}{*}{$\mathrm{V}(\%)$} & \multirow[t]{2}{*}{$\begin{array}{r}\text { CEC clay } \\
\mathrm{cmol}^{(+)} \mathrm{kg}^{-1}\end{array}$} & \multicolumn{4}{|c|}{ Organic matter } & \multirow[t]{2}{*}{$\begin{array}{l}\mathrm{P}_{2} \mathrm{O}_{5} \\
(\mathrm{ppm})\end{array}$} & \multirow[t]{2}{*}{$\operatorname{ESP}(\%)$} \\
\hline & & $\mathrm{Ca}^{2+}$ & $\mathrm{Mg}^{2+}$ & $\mathrm{K}^{+}$ & $\mathrm{Na}^{+}$ & S & & & & $\begin{array}{l}\mathrm{OC} \\
(\%)\end{array}$ & $\begin{array}{l}\mathrm{OM} \\
(\%)\end{array}$ & $\begin{array}{r}\mathrm{N} \\
(\%)\end{array}$ & $\mathrm{C} / \mathrm{N}$ & & \\
\hline \multirow[t]{3}{*}{ DMC } & $\mathrm{F} 1$ & 5.52 & 3.44 & 0.17 & 0.12 & 9.25 & 19.28 & 47.97 & 79.9 & 1.65 & 2.85 & 0.41 & 4.02 & 0.35 & 0.62 \\
\hline & $\mathrm{F} 2$ & 9.76 & 0.96 & 0.17 & 0.12 & 11.01 & 16.16 & 68.13 & 47.2 & 1.71 & 2.95 & 0.52 & 3.28 & 0.49 & 0.74 \\
\hline & F3 & 4.96 & 1.76 & 0.11 & 0.12 & 6.95 & 14.14 & 49.15 & 49.8 & 1.59 & 2.74 & 0.43 & 3.69 & 0.78 & 0.84 \\
\hline \multirow[t]{3}{*}{ DS } & $\mathrm{F} 1$ & 4.56 & 0.96 & 0.06 & 0.12 & 5.7 & 17.52 & 33.04 & 51.0 & 0.86 & 1.48 & 0.41 & 2.09 & 0.75 & 0.68 \\
\hline & $\mathrm{F} 2$ & 2.64 & 2.16 & 0.03 & 0.12 & 4.95 & 14.48 & 34.18 & 67.5 & 0.49 & 0.84 & 0.35 & 1.4 & 1.12 & 0.82 \\
\hline & F3 & 3.60 & 3.04 & 0.06 & 0.12 & 6.28 & 18.48 & 33.98 & 112.5 & 0.80 & 1.37 & 0.33 & 2.42 & 0.95 & 0.65 \\
\hline \multirow[t]{3}{*}{$\mathrm{TS}$} & $\mathrm{F} 1$ & 5.28 & 0.48 & 0.88 & 0.12 & 6.76 & 18.88 & 35.80 & 152.2 & 1.10 & 1.90 & 0.26 & 4.23 & 0.55 & 0.63 \\
\hline & $\mathrm{F} 2$ & 4.08 & 0.24 & 0.03 & 0.12 & 4.47 & 18.08 & 24.72 & 98.5 & 1.16 & 2.00 & 0.34 & 3.41 & 0.82 & 0.66 \\
\hline & F3 & 3.92 & 0.64 & 0.06 & 0.12 & 4.74 & 20.48 & 23.14 & 142.0 & 1.01 & 1.74 & 0.37 & 2.72 & 0.81 & 0.58 \\
\hline \multicolumn{2}{|c|}{ Control sample } & 7.36 & 0.56 & 0.06 & 0.12 & 8.1 & 20.16 & 40.17 & 113.6 & 1.56 & 2.69 & 0.54 & 2.88 & 0.30 & 0.59 \\
\hline & $\mathrm{CV}$ & 0.387 & 0.713 & 1.459 & 0.000 & 0.308 & 0.117 & 0.341 & 0.423 & 0.345 & 0.347 & 0.183 & 0.293 & 0.305 & 0.123 \\
\hline & SD & 1.90 & 1.08 & 0.25 & 0.00 & 2.06 & 2.05 & 13.26 & 37.63 & 0.40 & 0.69 & 0.07 & 0.89 & 0.22 & 0.08 \\
\hline
\end{tabular}

CV: coefficient of variation; SD: standard deviation.

of the TS system $\left(18.08-20.48 \mathrm{cmol}(+) \mathrm{kg}^{-1}\right)$ and the F1 fertilization level of the DMC system $\left(19.28 \mathrm{cmol}(+) \mathrm{kg}^{-1}\right)$ (Table 4). Base saturation rates were relatively low in both DS (33.04-34.18\%) and TS (23.14-35.80\%), when compared to the control sample $(40.17 \%)$ and the DMC system (49.15-68.13\%). The CEC clay of different soils was high and ranged from 47.2 to $152.2 \mathrm{cmol}(+) \mathrm{kg}^{-1}$ (Table 4). Total nitrogen and soil OM values were globally weak, but were high in the control sample ( 0.54 and $2.69 \%$, respectively) and in the DMC system $(0.41-0.52$ and $2.74-2.85 \%$, respectively) than in the two conventional systems $(0.26-0.41$ and $0.84-2.00 \%$, respectively) (Table 4 ). Available P values were low, and high values were recorded in the conventional systems. Except $\mathrm{Ca}^{2+}, \mathrm{Mg}^{2+}$ and $\mathrm{K}^{+}$, of which values were highly variable (CV > 35\%), all the soil characteristic values were slightly to moderately variable (Table 4 ).

\subsection{Correlation between Sorghum yields and rainfall}

Yields in each cropping system were considered separately for each fertilization level, and compared with cumulated rainfall in the studied site for 11 years (Table 2). No significant correlations were found between cumulated rainfall and yields (Fig. 3). All the coefficient of correlation values were below 0.5 .

\subsection{Suitability evaluation for Sorghum production}

The mean annual temperature and the mean annual rainfall of the study site were within $28^{\circ} \mathrm{C}$ and $800 \mathrm{~mm}$, respectively; 


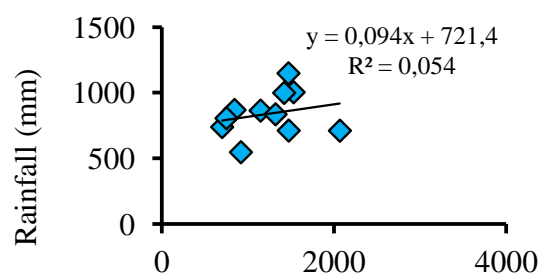

F1, DMC
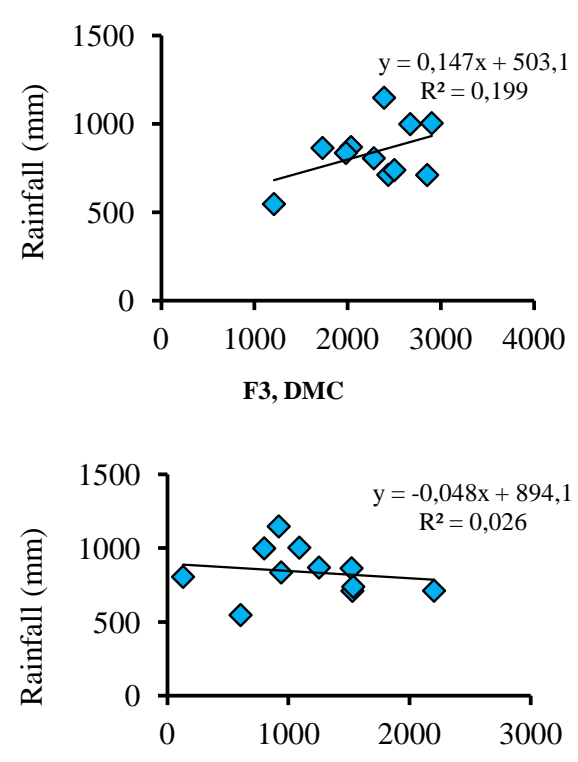

F2, DS

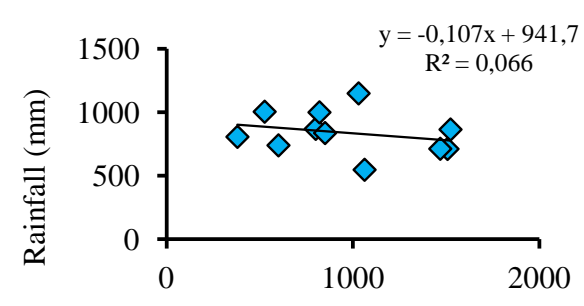

F1, TS

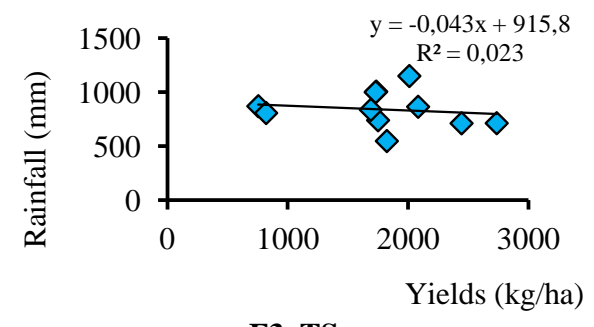

F3, TS

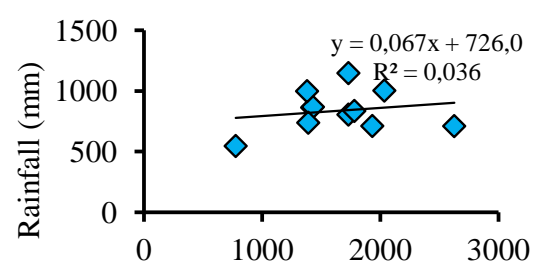

F2, DMC

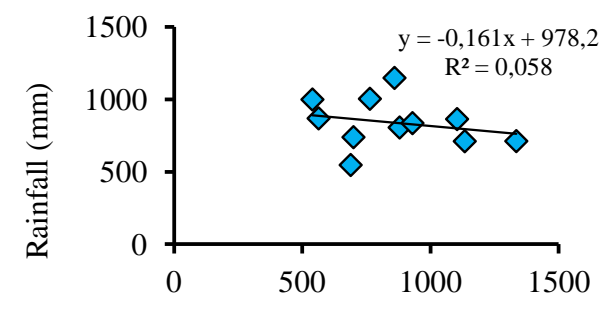

F1, DS

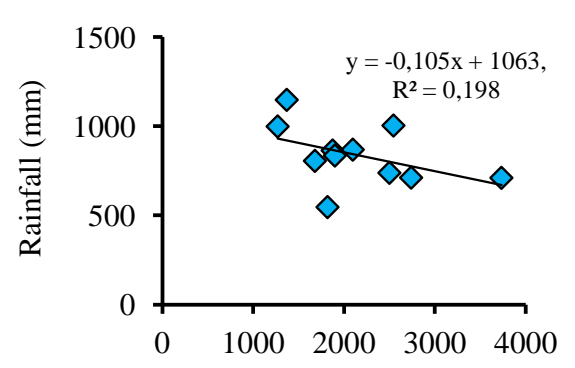

F3, DS

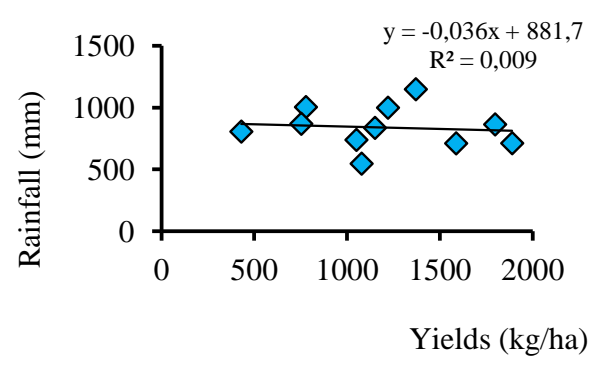

F2, TS

Figure 3. Plots of annual rainfall vs. yields in the three cropping systems and corresponding levels of fertilization. 
Table 5. Land suitability evaluation.

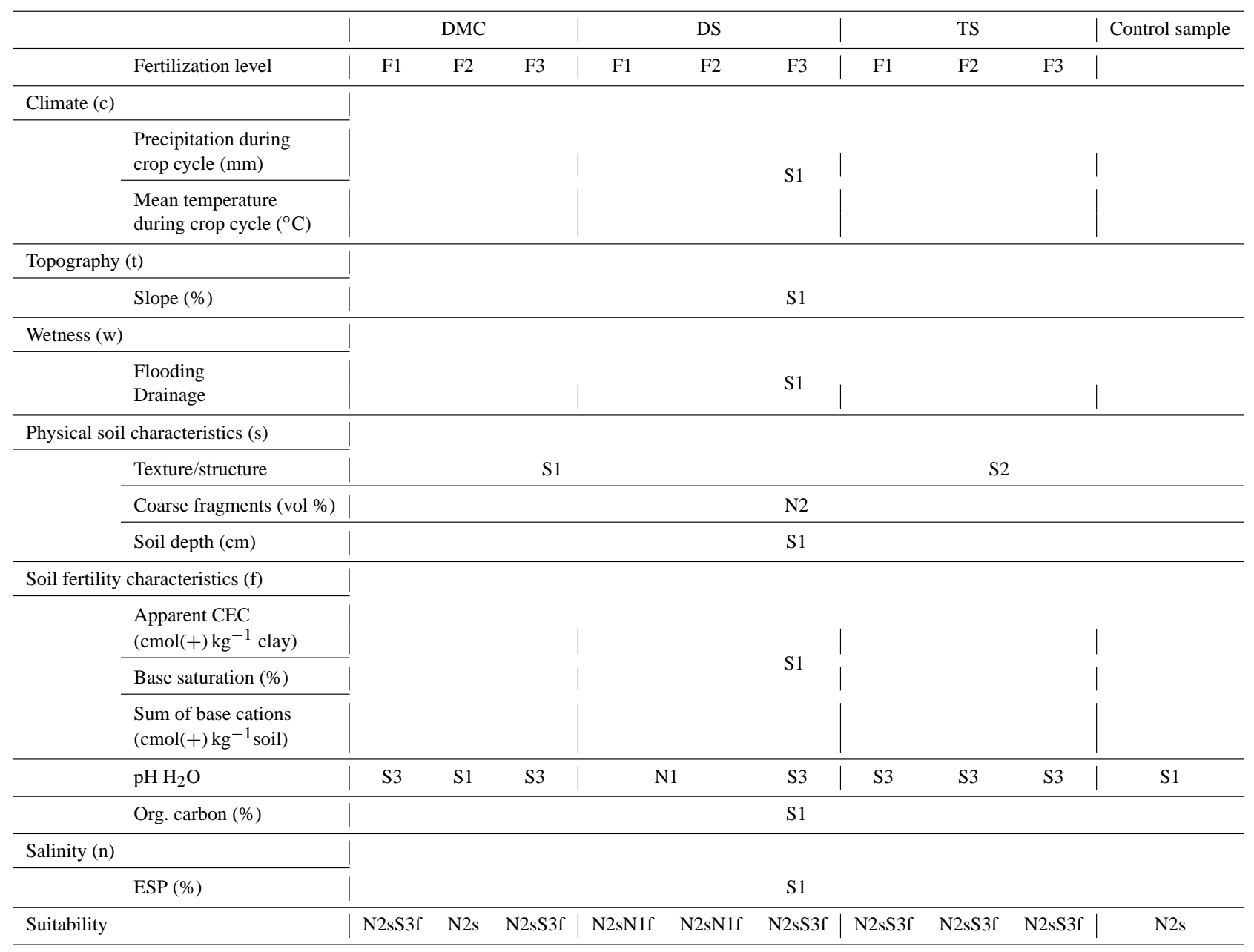

hence they all fell within the S1 (highly suitable) class with reference to temperature and rainfall requirements (Table 5). All soils were not flooded and were well drained, and therefore qualified for the S1 class when drainage and flooding were considered (Table 5). Looking at the textural class as the evaluation criteria, soils of the control sample, soils under TS and soils of the fertilization level F3 under DS qualified into the S2 class, while those under DMC and soils of the fertilization levels F1 and F2 under DS qualified into the S1 class (Table 5). Coarse materials (nodules) constituted about $90 \%$ of the volume in the B horizon, corresponding to the $\mathrm{N} 2$ class (Table 5). The soil depth was over $50 \mathrm{~cm}$, corresponding to the $\mathrm{S} 1$ class (Table 5). Considering the soil $\mathrm{pH}$, only the control plot and the soil under F2 and DCM were evaluated as being in the S1 class, while soils under TS and the fertilization levels F1 and F3 of DCM, and F3 of DS were evaluated as being in the S3 class, and F1 and F2 of DS were qualified as being in the $\mathrm{N} 1$ class (Table 5). All the other soil fertility characteristics, namely apparent CEC, base saturation, sum of exchangeable cations and organic carbon belonged to S1 class (Table 5). As for soil salinity, ESP (exchange sodium percentage) values were low $(<1 \%)$, belonging then to the 0-10 interval, which permitted all the soils to be qualified into the highly suitable class, S1 (Table 5).

Globally, all studied soils were permanently not suitable (N2) for Sorghum due to the high percentage of coarse fragments (nodules) (Table 5). In addition, F1 and F2 of the DS system were currently not suitable (N1) due to low soil $\mathrm{pH}$ values (5.1 and 4.9, respectively), while $\mathrm{F} 1$ and $\mathrm{F} 3$ of the DMC system, F3 of DS system and F1, F2 and F3 of TS were marginally suitable (S3) for Sorghum due to the same low soil $\mathrm{pH}$ values (5.2-5.3) (Table 5). Only F2 of the DMC system and the control plot were not subjected to soil fertility problems due to soil $\mathrm{pH}$ problems (Table 3 ). Their $\mathrm{pH}$ values were weakly acidic (5.6-5.7) (Table 3). 


\section{Discussion}

\subsection{Supply of nutrients}

The percentage of nitrogen in the fertilizer doses applied was high ( $22 \%$ of N in NPK) and there was an additional supply of nitrogen in the DCM system in the form of urea ( $46 \%$ of $\mathrm{N}$ in urea). It resulted in high yields of Sorghum and biomass produce by Brachiaria depending on the availability of nitrogen to plants as shown by crop yields in the fertilization level F3 of the DMC system. The effect of OM, incorporated or mulched, had long been recognized and practised, but recent research in Indonesia only dealt with OM management in relation to Al, P, and K behaviour (Sri Adiningsih et al., 1987), not with N supply processes in soils (Sudjadi et al., 1989). Previous works had reported that OM application, whether incorporated or applied as mulch or as part of alley cropping, increased crop yields and with a positive interaction with lime, P, or K. Higher yields require more nitrogen, so it could be concluded that the system released more nitrogen to produce higher yields (Sudjadi et al., 1989). It was noted that in order to increase the levels of nitrogen or OM in the soils it was necessary to increase $P$ reserves through fertilizer application (Sudjadi et al., 1989; Augusto et al., 2013). However, if nitrogen was the most important nutrient for crop growth and yield levels, it was also an element difficult to manage in fertilization. As optimal doses of nitrogen and phosphorous could stimulate the growth and productivity of crops (Naudin et al., 2010), likewise, their excess could increase their transfer from the soils to water (Silburn and Hunter, 2009; Novara et al., 2013). In addition, continuous nitrogen use was known to result in rapid soil acidification on low buffered soils as shown by low $\mathrm{pH}$ values obtained in the studied soils (Jones, 1976).

\subsection{Impact of cropping systems on Sorghum productivity}

Correlation values between crop yields and rainfall were not significant. This means that the results obtained were those of different management put in place in the studied site. Finally, DMC systems had higher yields of Sorghum in all levels of fertilization. The increase in crop yields in the DMC system was in line with results already observed in many other agroecologies such as Brazil (Blancaneaux et al., 1993), Madagascar (Reboul, 1997; Naudin et al., 2011), USA, Canada, Australia, Argentina, India, Turkey and many other countries in the world (Derpsch and Friedrich, 2009). This increase of yields showed that cropping systems had an impact on the Sorghum yields. Nevertheless, high yields also caused loss of mineral elements during crops exportation. So, if the DMC system could increase crop yields, seed exportation might be more important and consequently the exportation of mineral elements. Thereafter, subsequent supply of nutritive substances would be necessary. On the opposite site, crop yields in conventional systems were below those of DMC systems during some years. Also, yields obtained in the DS were sometimes lower than those obtained in TS. This could be due to soil cultivation. Indeed, the operations of returning and loosening the soil in the TS had been described as allowing good growth and good rooting of plants, in addition to the fact that they eliminated weeds susceptible to compete with the cultivated plants (Michellon et al., 2011). Poor yields of Sorghum in DS might, on the contrary, be due to no-till farming and insufficient biomass in this cropping system.

\subsection{Impact of fertilization levels on Sorghum productivity}

Sorghum yields increased with levels of fertilization. This meant that subsequent inputs of phosphorus and potassium, but especially nitrogen, were crucial for the productivity of Sorghum. Also, high levels of nitrogen fertilizer in addition to urea, as was the case in the Sorghum-Brachiaria association, justified the high yields obtained in DMC systems. Moreover, in the fertilization levels F1 and F2, the mean yield values of Sorghum, which were 960 and $1192 \mathrm{~kg} \mathrm{ha}^{-1}$ in the TS, respectively, were higher than those of DS, where $863 \mathrm{~kg} \mathrm{ha}^{-1}$ was obtained for F1 and $1139 \mathrm{~kg} \mathrm{ha}^{-1}$ for F2. Together with the till method, fertilization levels had a positive effect on Sorghum yields in the TS compared to the no-till system. Furthermore, the mean Sorghum yields in DS at fertilization level F3 $\left(2138 \mathrm{~kg} \mathrm{ha}^{-1}\right)$ rivalled that of DMC systems $\left(2270 \mathrm{~kg} \mathrm{ha}^{-1}\right)$ and exceeded mean yields in the TS in the same fertilization level $\left(1780 \mathrm{~kg} \mathrm{ha}^{-1}\right)$. So, it could be deduced that no-till farming techniques would need fertilizer supplements to express their productive potential. Combined with quantities of herbicide that required DS, as indicated by Barruiso et al. (1994), this system would induce excessive use of chemical elements. This involved expenses and highlights the risks of environmental pollution (Thapa and Yila, 2012). For nitrogen mainly, non-compliance dates and modes of spreading in rainfed crops caused losses by runoff likely to reach surface waters (Greenwood et al., 1980; Pallo et al., 2008). Despite the increase in Sorghum yields using fertilizers, yields of fertilization levels F3 were very unstable. This instability was more pronounced in TS $\left(1823 \mathrm{~kg} \mathrm{ha}^{-1}\right.$ in $2002,2736 \mathrm{~kg} \mathrm{ha}^{-1}$ in $2005,755 \mathrm{~kg} \mathrm{ha}^{-1}$ in 2007). This suggested that even if mineral fertilizers contributed to increase yields, they could also reduce in long-term soil productivity due to the degradation of the soil properties (Araya et al., 2010; Thapa and Yila, 2012). Sorghum yields in the long term would not be limited only on the quantity of fertilizer; it would need other types of fertilizers susceptible to offset losses caused by the exportation of crops. 


\subsection{Consequences of land management on water availability}

Coarse texture led to the loss of water by infiltration. In addition, Soutou et al. (2005) and Naudin et al. (2005) reported a good porosity, especially in DMC systems at the beginning and during the growing season, and only at the beginning of the growing season in the TS system. Indeed, in the DMC systems, roots of cover crops contributed to the infiltration of water, increasing water availability (Abrecht and Bristow, 1990; Scopel et al., 1999) and water use efficiency (Fischer et al., 2002). In dry climates, the soil was more humid under DMC (elimination of surface runoff, limited evaporation and increased water retention capacity) (AFD/FFEM, 2007), in line with Gao et al. (2014), who stated that the deposition of fine soil particles during vegetation restoration, as increasing clay contents in this system, led to an increase in the water-holding capability of soils. The roots of cover plants also captured deep moisture, thus improving the water balance (AFD/FFEM, 2007; Araya et al., 2011; Brevik et al., 2015). Furthermore, plant cover reduced evaporation since the soil was protected from direct sunlight and sharp thermal peaks, decreased the mechanical impact of raindrops on the soil and improved water infiltration, thus reducing runoff and soil loss (AFD/FFEM, 2007; García-Orenes et al., 2009; Perkins et al., 2013; Olang et al., 2014; Costa et al., 2015). Tillage in the TS ensured a temporarily better water regime in the soil (Singh et al., 2014). Infiltration conditions described here would be limited when taking into consideration the risks of water drainage into greater depths; the water then becomes inaccessible to crops due to the high percentage of nodules below the Ap horizon. In this case, the risk had to be compensated by plants with highly developed roots.

\subsection{Consequence of land management on the mineralization of soil organic matter}

Soil OM was an essential component of soil quality, governing processes like carbon sequestration, nutrient cycling, water retention and soil aggregate turnover (Van Leeuwen et al., 2015). Low mineral element contents in the soil were accentuated by low levels of soil OM. Soil OM contents, ranging from $0.84 \%$ in the fertilization level F2 of the DS, to $2.95 \%$ at the same fertilization level in DMC systems, were outright below the $7.24 \%$ reported by Reboul (1997) under extremely well-developed cover after 3 years' trial of DMC systems in the highlands of Madagascar. High OM mineralization rate in Zouana might be due to environmental conditions, characterized by high temperatures $\left(28^{\circ} \mathrm{C}\right)$ and humidity brought by rains in the beginning of the agricultural campaign. Moreover, Bikay (2004) found that in the site of Zouana, biological activity was high in DMC systems with Brachiaria. This was in line with observations of GarcíaOrenes et al. (2010) which stated that addition of available organic substrates would promote the growth and activity of indigenous microorganisms. The accumulation of biomass on the soil surface in the DMC systems, while increasing soil biological activity, intensified the mineralization process of $\mathrm{OM}$, leading thus to rapid mineralization of soil OM, which would therefore improve soil structure (García-Orenes et al., 2009; Costa et al., 2015) and plant nutrition (Chabanne et al., 2001; Séguy et al., 2001). In addition, $\mathrm{C} / \mathrm{N}<6$ suggested that the OM had a high rate of microbial decomposition in the soil (Tabi et al., 2012). This activation of biological activity was enhanced by nitrogen fertilizer supply, such as urea used in this study. The OM losses by mineralization were responsible for low minerals contents, nitrogen leakage in the atmosphere and carbon emission in the form of $\mathrm{CO}_{2}$. In addition, the decrease of the CEC and the agricultural potential of the soil, were also due to the degradation of soil OM. In these soils, characterized by low soil OM content, the organo-mineral particle-size fractions should then be considered of great significance both in amount and in their capacity as medium- and long-term reservoirs for organic-bonded plant nutrients (Christensen, 1987; Caravaca et al., 1999), by physically protecting some OM fractions (Hassink, 1997). Also, benefits of mulch as contributors to increase soil carbon contents (Neto et al., 2010) or provision of nitrogen for subsequent crop growth (Maltas et al., 2009), were directly proportional to the amount of mulch and its content of each element. In addition, the studied soil textures were sandy, and the small quantity of clay might not allow high formation of clay-humic complexes. Indeed, clay-protected OM, leading to a higher proportion of clay-stored organic carbon in cultivated soil, especially in the tillage treatments (Tiessen and Stewart, 1983; Cerri et al., 1989; Bruun et al., 2015). This was in line with Silva et al. (1994) who reported losses of $41 \%$ (clay soils), $76 \%$ (loamy soils) and $80 \%$ (sandy soils) of the original soil organic carbon stock after 5 years of heavy harrowing for cultivation of soybean.

\subsection{Evolution of physical and chemical properties of soils and Sorghum suitability}

From the particle size distribution viewpoint, clay contents were more expressed in the DMC and DS than in the TS, whose content was similar to that of the control sample. The larger amount of biomass in the DMC and DS might induce higher biological activity that would foster an increase in clay contents by biological upwelling. In fact, Bikay (2004) showed that termites represent the more abundant macrofauna under DMC. They were more active in semi-arid and arid regions than other macro-fauna (Lal, 1988). They influenced soil texture by bringing the fine fraction to the surface, for constructing mounds and feeding galleries (Lal, 1988). Except the fertilization level F2 in DS where the $\mathrm{pH}$ was acidic (4.9), $\mathrm{pH}$ values were globally weakly acidic, and a value identical to that of the control sample (5.6) was even obtained in the fertilization level F2 of the DCM system (5.7). This showed that land management had negative ef- 
fects on soil acidity. Indeed, during the mineralization of the soil OM, ammonia was formed and transformed thereafter into ammonium ions which were nitrified, and hydronium ions were produced in soil solution, making the soil acidic (Asuming-Brempong, 2014). Acidification might also be attributed to the increasing use of acidifying $\mathrm{N}$ mineral fertilizers, leaching of bases and continuous mining of bases through export of the Sorghum harvest (Tabi et al., 2013). Urea was known to be acidifying, but some fertilizers such as ammonium sulfate were about two times more acidifying than urea (Fageria et al., 2010). This acidity led to the decrease of soil fertility where soils were currently not suitable (F1 and F2 of the DS system) and marginally suitable (F1 and F3 of the DMC system, F3 of DS and F1, F2 and F3 of TS systems) for Sorghum. At this stage an inverse situation could occur, leading again to the progressive conservation of the OM concomitantly to the increase of the soil acidity. Indeed, soil acidity also influenced the amount of OM stored in the soil by retarding decomposition processes (Jordan, 1985) by (1) reducing the microbial and fauna activity, (2) producing scleromorphous leaves containing small amounts of proteinous substances (N, P and S) and large amounts of structural material $-\mathrm{C} / \mathrm{N}$ (and also $\mathrm{C} / \mathrm{P}$ ) ratios of such materials were high in the range of 20-30 instead of the usual range of 10-15 - and (3) forming relatively stable Al-OM complexes.

The sum of exchangeable bases and base saturation rate were globally higher in the DMC system than in conventional systems where their values were almost similar. The absence of tillage in the DMC system greatly reduced the risk of runoff and erosion, which would inevitably lead to the decrease in nutrient losses and thus in soil exchangeable bases (Scopel and Findeling, 2001). This rate was not far from that of the control sample (40\%). High base saturation rate in the DMC system was attributed to upwelling of minerals from deep horizons via Brachiaria root systems (AFD/FFEM, 2007). Soils were desaturated in conventional systems, especially in the TS system where the values obtained were around $20 \%$. Soils' desaturation in conventional systems could be attributed to leaching of nutrients released at the end of the agricultural campaign, accentuated by a low biomass rate. In addition, since soil textures of samples were sandy, sandy soils generally had low nutrients, while clayey soils usually had high nutrients due to their high adsorption capacity and low leaching losses (Shamsuddin and Bhatti, 2001).

The average soil OM content $(2.84 \%)$ in DMC systems was of the same order of magnitude as the proportion of the control soil $(2.69 \%)$. These soil OM contents in DMC systems, higher than those of DS and TS systems, meant that the vegetation cover permitted the soil OM content to be maintained (Mekuria and Aynekulu, 2013), favoured by regular supply of mulch (AFD/FFEM, 2007). The soil fertility quality in DMC systems was partly due to soil OM contents that concurred to increase the sum of exchangeable bases values and particularly, those of the CEC (Thompson et al., 1989;
Asadu et al., 1997). The increase in clay content of DMC systems also contributed to the physical protection of soil OM. The soil OM mean proportion in the DS $(1.35 \%)$ and TS $(1.88 \%)$ suggested a loss of soil OM. This was due to the predominance of sandy texture in these conventional systems that limited the soil OM residence time. In addition, the low biomass and accelerated mineralization made DS less favourable to preservation of soil OM. This was confirmed by the average carbon content, which was lower, $0.71 \%$ against $1.09 \%$ in the TS and $1.65 \%$ in DMC systems. Soil erosion imputable to conventional agricultural practices also led to a loss of soil OM. In addition, repeated tillage in the TS cropping system fragmented the soils and favoured soil OM mineralization (Houyou et al., 2014). Globally, phosphorus levels were low in the soil. This was due to plants' uptake which led to the decrease of phosphorus contents in the soil at the end of the agricultural campaign.

\section{Conclusions}

The study aimed to analyse the impact of different types of management (DS, TS and DMC) at different levels of fertilization on Sorghum yields, soil fertility and the rehabilitation of hardé soils in the Far North region of Cameroon. From the crop yields viewpoint, the average yields of Sorghum between different cropping systems from 2002 to 2012 increase from F1 to F3. On the soil fertility point of view, it is noted that there is an acidification of soils in different experimental plots due to losses of mineral elements through leaching, exportation of crops and use of nitrogen fertilizer, and an improvement of physical and chemical properties of soils in the DMC systems from F1 to F3 fertilization levels, contrary to the other systems. Globally, DMC systems have higher yields of Sorghum in all levels of fertilization, increasing from F1 to F3. Correlation values between crop yields and rainfall were not significant, meaning that the results obtained are those of different management systems carried out in the studied site. The study soils which were previously permanently not suitable (N2) for Sorghum due to the high percentage of nodules, are in addition marginally suitable to currently not suitable for Sorghum, due to low soil $\mathrm{pH}$ values as a result of being under different management systems.

Acknowledgements. The authors wish to thank the SODECOTON authorities in Maroua who provided both the internship and the already available data. We are grateful to Mr. Baipame, in charge of agro-ecological activities of SODECOTON in Maroua who always accompanied us in the study site.

Edited by: P. Pereira 


\section{References}

Abrecht, D. G and Bristow, K. L.: Maize seedling response to the soil environment at varying distances from a mulched soil-bare soil boundary, Soil Till. Res., 15, 205-216, 1990.

AFD/FFEM: Direct Seeding Much-Based Cropping Systems (DMC), Paris, France, 2007.

Araya, A., Keesstra, S. D., and Stroosnijder, L.: Simulating yield response to water of Teff (Eragrostis tef) with FAO's AquaCrop model, Field Crops Res., 116, 196-204, doi:10.1016/j.fcr.2009.12.010, 2010.

Araya, A., Stroosnijder, L., Girmay, G., and Keesstra, S. D.: Crop coefficient, yield response to water stress and water productivity of teff (Eragrostis tef (Zucc.), Agricult. Water Manage., 98, 775783, doi:10.1016/j.agwat.2010.12.001, 2011.

Asadu, C. L. A., Diels, J., and Vanlauwe, B.: A comparison of the contributions of clay, silt and organic matter to effective CEC of soils of sub-Saharan Africa, Soil Sci., 162, 785-794, 1997.

Asuming-Brempong, S.: Sustainable growth of rice in Ghana: the role of biofertilizers (Phosphate solubilizing microorganisms and Azolla anabaena) to rice improvement, Global Adv. Res. J. Agricult. Sci., 3, 1-7, 2014.

Augusto, L., Delerue, F., Gallet-Budynek, A., and Achat, D. L.: Global assessment of limitation to symbiotic nitrogen fixation by phosphorus availability in terrestrial ecosystems using a meta-analysis approach, Global Biogeochem. Cy., 27, 804-815, doi:10.1002/gbc.20069, 2013.

Barruiso, E., Calvet, R., and Cure, B.: Incidence de la simplification du travail du sol sur le comportement des produits phytosanitaires: conséquence sur les risques de pollution, in: Simplification du travail du sol (Éd), Paris, France, 16 Mai 1991, 105-124, 1994.

Bikay, S.: Inventaire de la macrofaune en culture cotonnier sous quatre modes de gestion des sols: Cas de Windé Pintchoumba (Nord) et Zouana (Extrême-Nord), Mémoire d'ingénieur agronome, Université de Dschang, Faculté d'Agronomie et des Sciences Agricoles (FASA), Cameroun, CIRAD, 2004

Bilgo, A., Serpantié, G., Masse, D., Fournier, J., and Hien, V.: Carbon, Nitrogen, and fine particles removed by water erosion on crops, fallows, and mixed plots in Sudanese savannas (Burkina Fasso), edited by: Roose, E. J., Lal, R., Feller, C., Barthès B, and Stewart, B. A., CRC, Taylor and Francis, 125-142, 2006.

Biro, K., Pradhan, B., Buchroithner, M., and Makeschin, F.: Land use/land cover change analysis an its impact on soil properties in the Northern part of Gadarif region, Sudan, Land Degrad. Dev., 24, 90-102, doi:10.1002/ldr.1116, 2013.

Blancaneaux, P., De Freitas, P. L., Amabile, R. F., and De Carvalho, A.: Le semis direct comme pratique de conservation des sols des cerrados du Brésil central, Cahier Orstom, Série Pédologie, 28, 253-275, 1993.

Boli Baboule, Z., Bep Aziem, A., and Roose, E.: Enquête sur l'érosion en région cotonnière du Nord Cameroun, Bull-Réseau Erosion, 127-138, 1991.

Boli Baboule, Z.: Fonctionnement des sols sableux et optimisation des pratiques culturales en zone soudanienne humide du NordCameroun, Thèse de doctorat en Sciences de la Terre, ORSTOM, Montpellier, France, 1996.

Bray, R. H. and Kurtz, L. T.: Determination of total organic and available forms of phosphorus in soils, Soil Sci., 59, 22-229, 1945.
Brevik, E. C., Cerdà, A., Mataix-Solera, J., Pereg, L., Quinton, J. N., Six, J., and Van Oost, K.: The interdisciplinary nature of SOIL, SOIL, 1, 117-129, doi:10.5194/soil-1-117-2015, 2015.

Brown, G. G., Benito, N. P., Pasini, A., Sauter, K. D., Guimaraes, M. F., and Torres, E.: No-tillage greatly increases earthworm populations in Parana state, Brazil, Pedobiologia, 47, 764-771, 2002.

Bruun, T. B., Elberling, B., de Neergaard, A., and Magid, J.: Organic carbon dynamics in different soil types after conversion of forest to agriculture, Land Degrad. Dev., 26, 272-283, doi:10.1002/ldr.2205, 2015.

Caravaca, F., Lax, A., and Albaladejo, J.: Organic matter, nutrient contents and cation exchange capacity in fine fractions from semiarid calcareous soils, Geoderma, 93, 161-176, 1999.

Cerdà, A.: Aggregate stability against water forces under different climates on agriculture land and scrubland in southern Bolivia, Soil Till. Res., 36, 1-8, 2000.

Cerdà, A., Flanagan, D. C., le Bissonnais, Y., and Boardman, J.: Soil erosion and agriculture, Soil Till. Res., 106, 107-108, doi:10.1016/j.still.2009.10.006, 2009a.

Cerdà, A., Giménez-Morera, A., and Bodí, M. B.: Soil and water losses from new citrus orchards growing on sloped soils in the western Mediterranean basin, Earth Surf. Proc. Land., 34, 1822 1830, 2009b.

Cerri, C. C., Victória, R. L., Andreux, F., Vitorello, V. A., and Feller, C.: Organic matter and natural carbon-13 distribution in forested and cultivated oxisols, Soil Sci. Soc. Am. J., 53, 7737781989.

Chabanne, A., Boyer, J., and Séguy, L.: Impact of plant covers on Pelargonium $\times$ asperum yields and soil biology (macrofauna) in Réunion (France), in: Conservation Agriculture, A Worldwide Challenge, edited by: Garcia Torres, L., Benites, J., and Martínez Vilela, A., First World Congress on conservation agriculture proceedings, Madrid, Spain, 1-5 October 2001, 1, 85-92, 2001.

Christensen, B. T.: Decomposability of organic matter in particle size fractions from field soils with straw incorporation, Soil Biol. Biochem., 19, 429-435, 1987.

Costa, J. L., Aparicio, V., and Cerdà, A.: Soil physical quality changes under different management systems after 10 years in the Argentine humid pampa, Solid Earth, 6, 361-371, doi:10.5194/se-6-361-2015, 2015.

Derpsch, R. and Friedrich, T.: Development and Current Status of No-till Adoption in the World, Proceedings on CD, 18th Triennial Conference of the International Soil Tillage Research Organization (ISTRO), Izmir, Turkey, 15-19 June, 2009.

Dongmo Ngoutsop, A.-L.: Territoires, troupeaux et biomasses: enjeux de gestion pour un usage durable des ressources au NordCameroun, Thèse Doctorat, Institut des Sciences et Industries du Vivant et de l'Environnement (Agro Paris Tech), Paris, France, 2009.

Ehabe, E. E., Bidzanga, N. L., Mba, C., Njukeng, J. N., de Barros, I., and Enjalric, F.: Nutrient flows in perennial crop-based farming systems in the humid forests of Cameroon, Am. J. Plant Sci., 1, 38-46, 2010.

Fageria, N. K., Dos Santos, A. B., and Moraes, M. F.: Influence of urea and ammonium sulfate on soil acidity indices in lowland rice production, Commun. Soil Sci. Plan., 41, 1565-1575, 2010.

Fischer, R. A., Santiveri, F., and Vidal, I. R.: Crop rotation, tillage and crop residue management for wheat and maize in the sub- 
humid tropical highlands - Part I: Wheat and legume performance, II: Maize and system performance, Field Crop. Res., 79, 107-137, 2002.

Gabathuler, E., Liniger, H. P., Hauert, C., and Giger, M.: Benefits of sustainable land management, WOCAT/UNCCD, University of Bern, Switzerland, Centre for Development and Environment (CDE), 2009.

Gao, X., Wu, P., Zhao, X., Wang, J., and Shi, Y.: Effects of land use on soil moisture variation in a semi-arid catchment: implications for land and agricultural water management, Land Degrad. Dev., 25, 163-172, doi:10.1002/ldr.1156, 2014.

García-Orenes, F., Cerdà, A., Mataix-Solera, J., Guerrero, C., Bodí, M. B., Arcenegui, V., Zornoza, R., and Sempere, J. G.: Effects of agricultural management on surface soil properties and soil-water losses in eastern Spain, Soil Till. Res., 106, 117-123, doi:10.1016/j.still.2009.06.002, 2009.

García-Orenes, F., Guerrero, C., Roldán, A., Mataix-Solera, J., Cerdà, A., Campoy, M., Zornoza, R., Bárcenas, G., and Caravaca, F.: Soil microbial biomass and activity under different agricultural management systems in a semiarid Mediterranean agroecosystem, Soil Till. Res., 109, 110-115, doi:10.1016/j.still.2010.05.005, 2010.

Greenwood, D. J., Cleaver, T. J., Turner, M. K., Hunt, J., Niendorf, K. B., and Loquens, S. M. H.: Comparison of the effects of nitrogen fertilizer on the yield, nitrogen content and quality of 21 different vegetable and agricultural crops, J. Agricult. Sci., 95, 471-485, doi:10.1017/S0021859600039514, 1980.

Harmand, J. M., Njitti, C. F., Bernard Reversat, F., Feller, C., and Oliver, R.: Variations de stock de carbone dans le sol au cours du cycle jachère arborée culture, Zone soudanienne du Cameroun, in La Jachère en Afrique Tropicale, J. Libbey, Eurotext, Paris, 706-713, 2000.

Hassink, J.: The capacity of soils to preserve organic $\mathrm{C}$ and $\mathrm{N}$ by their association with clay and silt particles, Plant Soil, 191, 7787, 1997. .

Houyou, Z., Bielders, C. L., Benhorma, H. A., Dellal, A., and Boutemdjet, A.: Evidence of strong land degradation by wind erosion as a result of rainfed cropping in the algerian steppe: a case study at Laghouat, Land Degrad. Dev., doi:10.1002/ldr.2295, online first, 2014.

Husson, O., Charpentier, H., Razanamparany, C., Moussa, N., Michellon, R., Naudin, K., Razafintsalama, H., Rakotoarinivo, C., Rakotondramanana, and Séguy, L.: Brachiaria sp, B. ruziziensis, B. brizantha, B. decumbens, B. humidicola: Chapitre 3.4.1. Fiches techniques plantes de couverture: légumineuses pérennes Brachiaria sp: B. ruziziensis, B. brizantha, B. decumbens, B. humidicola, in: Manuel pratique du semis direct à Madagascar, Antananarivo, CIRAD III, 2008.

Jones, M. J.: Effects of three nitrogen fertilizers and lime on $\mathrm{pH}$ and exchangeable cation content of different depths in cropped soils at two sites in the Nigerian Savanna, Trop. Agr., 53, 243-254, 1976.

Jordan, C. F.: Nutrient Cycling in Tropical Forest Ecosystems, J. Wiley, New York, 1985.

Kang, B. T. and Juo, A. S.: Effect of Forest Clearing on Chemical Properties and Crop Performance, IITA, Ibadan, 1982.

Kendall, H. W. and Pimentel, D.: Constraints on the expansion of the global food supply, Ambio, 23, 198-205, 1994.
Lal, R.: Effects of macrofauna on soil properties in tropical ecosystems, Agr. Ecosyst. Environ., 24, 101-116, 1988.

Landais, E. and Lhoste, P.: L'association agriculture-élevage en Afrique intertropicale: un mythe techniciste confronté aux réalités du terrain, Cahier Orstom, Série Science Humaine, 26, 217 235, 1990.

Leh, M., Bajwa, S., and Chaubey, I.: Impact of land use change on erosion risk: and integrated remote sensing geopraphic information system and modeling methodology, Land Degrad. Dev., 24, 409-421, doi:10.1002/ldr.1137, 2013.

Lemenih, M.: Effects of land use changes on soil quality and native flora degradation and restoration in the highlands of Ethiopia. Implications for sustainable land management, $\mathrm{PhD}$ thesis, Swedish University of Agricultural Sciences, Uppsala, 2004.

Letouzey, R.: Notice de la Carte Phytogéographique du Cameroun au $1: 500000$, Domaine Sahélien et Soudanien, Herbier National IRA, Yaoundé, Institut de la Carte Internationale de la Végétation, Toulouse, France, 1985.

Lieskovský, J. P. and Kenderessy, P.: Modelling the effect of vegetation cover and different tillage practices on soil erosion in vineyards: a case study in Vráble (Slovakia) using watem/sedem, Land Degrad. Dev., 25, 288-296, doi:10.1002/ldr.2162, 2014.

Maltas, A., Corbeels, M., Scopel, E., Wery, J., and Macena da Silva, F. A.: Cover crop and nitrogen. Effects on maize productivity in no-tillage systems of the brazilian cerrados, Agron. J., 101, 1036-1046, 2009.

Mandal, D. and Sharda, V. N.: Appraisal of soil erosion risk in the Eastern Himalayan region of India for soil conservation planning, Land Degrad. Dev., 24, 430-437, doi:10.1002/ldr.1139, 2013.

Marasas, M. E., Sarandón, S. J., and Cicchino, A. C.: Changes in soil arthropod functional group in wheat crop under conventional and no tillage systems in Argentina, Appl. Soil Ecol., 18, 61-68, 2001.

Mekuria, W. and Aynekulu, E.: Exclosure land management for restoration of the soils in degrade communal grazing lands in Northern Ethiopia, Land Degrad. Dev., 24, 528-538, doi:10.1002/ldr.1146, 2013.

Michellon, R., Husson, O., Moussa, N., Randrianjafizanaka, M. T., Naudin, K., Letourmy, P., Andrianaivo, A.-P., Rakotondramanana, R., Raveloarijoana, N., Enjalric, F., Penot, E., and Séguy, L.: Striga asiatica: a driving-force for dissemination of conservation agriculture systems based on Stylosanthes guianensis in Madagascar, in: Resilient food systems for a changing world/5th World Congress of Conservation Agriculture (WCCA) incorporating 3rd Farming System Design Conference, Brisbane, Australia, 26-29 September 2011, 213-214, 2011.

Muluneh, A., Biazin, B., Stroosnijder, L., Bewket, W., and Keesstra, S.: Impact of predicted changes in rainfall and atmospheric carbon dioxide on maize and wheat yields in the Central Rift Valley of Ethiopia, Reg. Environ. Change, 15, 1105-1119, doi:10.1007/s10113-014-0685-x, 2014.

Myers, N.: Gaia: An Atlas of Planet Management, Anchor Press/Doubleday, Garden City, NY, 1993.

Naudin, K., Adoum, O., Soutou, G., and Scopel, E.: Labour biologique contre labour mécanique: comparaison de leurs effets sur la structure du sol au Nord Cameroun, Cirad, 2005. 
Naudin, K., Gozé, E., Balarabe, O., Giller, K. E., and Scopel, E.: Impact of no tillage and mulching practices on cotton production in North Cameroon: a multilocational on-farm assessment, Soil Till. Res., 108, 67-68, 2010.

Naudin, K., Scopel, E., Andriamandroso, A. L. H, Rakotosolofo, M., Andriamarosoa Ratsimbazafy, N. R. S., Rakotozandriny, J. N., Salgado, P., and Giller, K. E.: Trade-offs between biomass use and soil cover, the case of rice-based cropping systems in the lake Alaotra region of Madagascar, Exp. Agr., 48, 194-209, 2011.

Naudin, K.: You can not eat your mulch and have it too - Cropping system design and trade-offs around biomass use for Conservation Agriculture in Cameroon and Madagascar, $\mathrm{PhD}$ thesis, Wageningen University, Wageningen, 2012.

Ndah, H. T., Schuler, J., Uthes, S., Zander, P., Triomphe, B., Mkomwa, S., and Corbeels, M.: Adoption potential for conservation agriculture in Africa: a newly developed assessment approach (QAToCA) applied in Kenya and Tanzania, Land Degrad. Dev., 26, 133-141, doi:10.1002/ldr.2191, 2015.

Neto, M. S., Scopel, E., Corbeels, M., Cardoso, A. N., Douzet, J.M., Feller, C., Piccolo, M. D. C. C., Cerri, C. C., and Bernoux, M.: Soil carbon stocks under no-tillage mulch-based cropping systems in the Brazilian Cerrado: an on-farm synchronic assessment, Soil Till. Res., 110, 187-195, 2010.

Novara, A., Gristina, L., Guaitoli, F., Santoro, A., and Cerdà, A.: Managing soil nitrate with cover crops and buffer strips in Sicilian vineyards, Solid Earth, 4, 255-262, doi:10.5194/se-4-2552013, 2013.

Olang, L. O., Kundu, P. M., Ouma, G., and Fürst J.: Impacts of land cover change scenarios on storm runoff generation: a basis for management of the Nyando basin, Kenya, Land Degrad. Dev., 25, 267-277, doi:10.1002/ldr.2140, 2014.

Pallo, F.-J., Sawadago, N., Sawadago, L., Sedogo, M., and Assa, A.: Statut de la matière organique des sols dans la zone sudsoudanienne au Burkina-faso, Biotechnology, Agronnmy Society and Environment, 12, 291-301, 2008.

Perkins, J., Reed, M., Akanyang, L., Atlhopheng, J., Chanda, R., Magole, L., Mphinyane, W., Mulale, K., Sebego, R., Fleskens, L., Irvine, B., and Kirkby, M.: Making land management more sustainable: experience implementing a new methodological framework in Botswana, Land Degrad. Dev., 24, 463-477, doi:10.1002/ldr.1142, 2013.

Pimental, D., Harvey, C., Resosudarmo, P., Sinclair, K., Kurz, D., Mcnair, M., Crist, S., Sphpritz, L., Fitton, L., Saffouri, R., and Blair, R.: Environmental and economic cost of soil erosion and conservation benefits, Science, 267, 1117-1123, 1995.

Pimentel, D.: Soil erosion: a food and environmental threat, Environmental, Development and Sustainnability, 8, 119-137, 2006.

Reboul, J. L.: Systèmes de cultures sans labour par semis direct sur couvertures permanentes des sols, adaptation et diffusion à Madagascar, CIRAD, 441-455, 1997.

Roose, E.: Introduction à la gestion conservatoire de l'eau, de la biomasse et de la fertilité des sols (GCES), Bulletin pédologique de la FAO, 70, 14-17, 1994.

Scopel, E. and Findeling, A.: Conservation tillage impact on rainfed maize production in semi-arid zones of western Mexico: importance of runoff reduction, in: Conservation Agriculture, A Worldwide Challenge, edited by: Garcia Torres, L., Benites, J., and Martínez Vilela, A., First World Congress on conservation agriculture proceedings, Madrid, Spain, 1-5 October, 1, 85-92, 2001.

Scopel, E., Chavez Guerra, E., and Arreola Tostado, J. M.: Direct seeding with crop residue mulch in western Mexico: can it improve soil water contents, Agricult. Dev., 21, 71-86, 1999.

Séguy, L., Bouzinac, S., and Maronezzi, A. C.: Cropping systems and organic matter dynamics, in: Conservation Agriculture, A Worldwide Challenge, edited by: Garcia Torres, L., Benites, J., and Martínez Vilela, A., First World Congress on conservation agriculture proceedings, Madrid, Spain, 1-5 October 2001, 2, 301-305, 2001.

Shamsuddin, T. and Bhatti, A.: Physical properties of soil, in: Soil Science, edited by: Basher, E. and Bantal, R., National Book Foundation, Islamabad, Pakistan, 2001.

Silburn, D. M. and Hunter, H. M.: Management practices for control of runoff losses from cotton furrows under storm rainfall. III. Cover and wheel traffic effects on nutrients $(\mathrm{N}$ and $\mathrm{P})$ in runoff from a black Vertosol, Aust. J. Soil Res., 47, 221-233, 2009.

Silva, J. E., Lemainski, J., and Resck, D. V. S.: Perdas de matéria orgânica e suas relações com a capacidade de troca catiônica em solos da região de cerrados do oeste baiano, Rev. Bras. Cienc. Solo, 18, 541-547, 1994.

Singh, K., Mishra, A. K., Singh, B., Singh, R. P., and Patra, D. D.: Tillage effects on crop yield and physicochemical properties of sodic soils, Land Degrad. Dev., doi:10.1002/ldr.2266, online first, 2014.

Smaling, E. M. A.: The soil nutrient balance: an indicator of sustainable agriculture in sub-Saharan Africa, The Fertilizer Society, Proceedings, 340, 1-18, 1993.

Soutou, G., Naudin, K., and Scopel, E.: Crop water balance in conventional and direct seeding mulch-based cotton cropping systems in North Cameroon, in: 3rd World Congress on Conservation Agriculture, Naïrobi, Kenya, 3-7 October, 2005.

Sri Adiningsih, J., Diah Setyorini, D. S., and Saenong, S.: Fertilizer Management to Improve Soil Fertility and Yield in Indonesia, INSFFER Planning Meeting Work-Shop, New Delhi, India, 20 September-October, 1987.

Suchel, J. B.: Les climats du Cameroun, Thèse Doct.ès-Lettres, University of Bordeaux, Bordeaux, France, III, 1987.

Sudjadi, M., Putu, I., Widjaja-Adhi, G., and Sri Adiningsih, J.: Management of nitrogen to improve its use efficiency in lowland and upland soils of indonesia, in: Proceedings of the Symposium: "Nutrient Management for Food Crop Production in Tropical Farming Systems", Universitas Brawijaya, MaLang, Indonesia, 19-24 October 1987, edited by: van der Helde, J., published jointly by: Institute for Soil Fertility (IB), 9750 RA, Haren, the Netherlands, and Universitas Brawijaya, Jalan Mayor Jenderal Haryono 163, Malang, Indonesia, Haren, the Netherlands, 95108, 1989.

Sys, C., Van Ranst, E., and Debaveye, J.: Land evaluation - Part I: Principles in land evaluation and crop production calculation, General Administration for development cooperation, Agricultural Publication No. 7, Brussels, Belgium, 1991a.

Sys, C., Van Ranst, E., and Debaveye, J.: Land evaluation - Part II: Methods in land evaluation, General Administration for development cooperation, Agricultural Publication No. 7, Brussels, Belgium, 1991b. 
Sys, C., Van Ranst, E., and Debaveye, J.: Land evaluation - Part III: Crop Requirements, International Training Center for Post Graduate Soil Scientists, Ghent University, Ghent, Belgium, 1993.

Tabi, F. O., Omoko, M., Boukong, A., Mvondo, Ze, A. D., Bitondo, D., and Fuh Che, C.: Evaluation of lowland rice (Oryza sativa) production system and management recommendations for Logone and Chari flood plain - Republic of Cameroon, Agricult. Sci. Res. J., 2, 261-273, 2012.

Tabi, F. O., Bitondo, D., Yinda, G. S., Kengmegne, S. S. A., and Ngoucheme, M.: Effect of long-term integrated soil fertility management by local farmers on nutrient status of a Typic Dystrandept under potato-based cropping system, Int. Res. J. Agr. Sci. Soil Sci., 3, 134-140, 2013.

Thapa, G. B. and Yila, O. M.: Farmers' land management practices and status of agricultural land in the Jos Plateau, Nigeria, Land Degrad. Dev., 23, 263-277, doi:10.1002/ldr.1079, 2012.

Thompson, M. L., Zhang, H., Kazemi, M., and Sandor, J. A.: Contribution of organic matter to cation exchange capacity and specific surface area of fractionated soil materials, Soil Sci., 148, 205-257, 1989.

Tiessen, H. and Stewart, J.: Particle-size fractions and their use in studies of soil organic matter. I I. Cultivation effects on organic matter composition in size fractions, Soil Sci. Soc. Am. J., 47, 509-14, 1983.
Tsozué, D., Haiwe, B. R., Louleo, J., and Nghonda, J. P.: Local initiatives of land rehabilitation in the Sudano-Sahelian region: case of hardé soils in the far north region of Cameroon, J. Soil Sci., 4, 6-16, doi:10.4236/ojss.2014.41002, 2014.

Van Leeuwen, J. P., Lehtinen, T., Lair, G. J., Bloem, J., Hemerik, L., Ragnarsdóttir, K. V., Gísladóttir, G., Newton, J. S., and de Ruiter, P. C.: An ecosystem approach to assess soil quality in organically and conventionally managed farms in Iceland and Austria, SOIL, 1, 83-101, doi:10.5194/soil-1-83-2015, 2015.

Walkey, A. and Black, I. A.: Determination of organic matter in soil, Soil Sci., 37, 549-556, 1934.

WRB.: World reference base for soil resources 2006, World Soil Resources Reports No. 103, FAO, Rome, 2006.

WRI.: World Resources Institute, Oxford University Press, New York, 1994.

Zhao, G., Mu, X., Wen, Z., Wang, F., and Gao, P.: Soil erosion, conservation, and eco-environment changes in the Loess Plateau of China, Land Degrad. Dev., 24, 499-510, doi:10.1002/ldr.2246, 2013. 